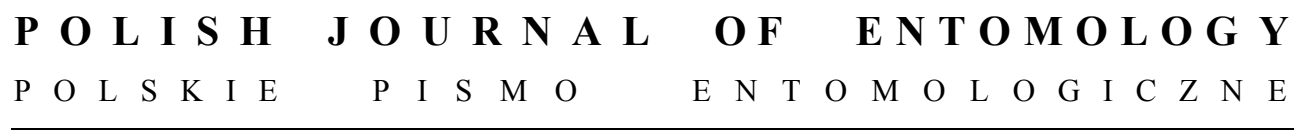

VOL. 81: $335-346$

Gdańsk

31 December 2012

DOI: $10.2478 / \mathrm{v} 10200-012-0014-\mathrm{y}$

\title{
Tortricidae (Lepidoptera) from the Tervuren Museum, 3: Hypsidracon MEYRICK and Gnathodracon gen. $\mathrm{n}$.
}

\author{
JÓZEF RAZOWSKI
}

Institute of Systematics and Evolution of Animals PAS, Sławkowska 17, 31-016 Kraków, Poland, e-mail: Razowski@isez.pan.krakow.pl

\begin{abstract}
Two genera and seven species of Afrotropical Tortricidae are discussed. One genus (Gnathodracon RAZOWSKI, gen. n.) and six species (Hypsidracon kururana RAZOWSKI, sp. n., Gnathodracon orbiculina RAZOWSKI, sp. n., G. arabuko RAZOWSKI, sp. n., G. yuhana RAzOwSKI, sp. n., G. lukimayumbe RAZOWSKI, sp. n., and G. monospina RAZOWSKI, sp. n.) are described. Prophaecasia strigulana KARISCH is transferred to Gnathodracon, comb. $\mathrm{n}$.
\end{abstract}

KEY WORDS: Lepidoptera, Tortricidae, Hypsidracon, Gnathodracon, new taxa, Afrotropics.

INTRODUCTION

Recent progress on the systematics of Afrotropical Tortricidae can be attributed primarily to AARVIK (2004), AARVIK \& KARISCH (2009), KARISCH (2008), and RAZOWSKI \& TREMATERRA (2008). Two catalogues, one by RAzowsKi \& KRÜGer (2007) and the other by RAZOWSKI et al. (2010), also contribute to our understanding of the family in this region. Despite these efforts, the tortricid fauna of the Afrotropical region is still poorly known. Hence, even small additions to our knowledge are important.

This paper is the third in a series based on the collection of the Royal Museum for Central Africa (RMCA). The particular parts will be published in the SHILAP of Madrid and the Polish Journal of Entomology.

\section{MATERIAL}

The material for this study is deposited in the Royal Museum for Central Africa (Tervuren, Belgium; RMCA) formerly known as the Tervuren Museum. It is described and 
discussed in the context of the Catalogue of the types of Tortricidae by RAZOWSKI et al. (2010). The collection includes representatives of Tortricinae (except for Phricanthini, Cochylini, and Euliini), Chlidanotinae (except for Chlidanotini and Hilarographini) and almost all groups of Olethreutinae. This paper deals with two Olethreutinae genera, Hypsidracon MEYRICK and Gnathodracon gen. $\mathrm{n}$.

The specimens were collected in Congo and Cameroon. Hypsidracon was collected at an elevation of $2910 \mathrm{~m}$; Gnathodracon species occupy mixed forest, stegia woodland, primary lowland forest, submontane forest and scrubby low vegetation at altitudes between 50 and $2910 \mathrm{~m}$.

\section{Acknowledgements}

The author is grateful to the authorities of the Royal Museum for Central Africa, Tervuren, represented by Dr Jurate De Prins, who provided this large, valuable collection for study. I thank Mr Witold Zajda, Kraków, for taking the photographs and arranging the plates. Special thanks are due to the anonymous reviewer for the edition of this paper.

\section{SYSTEMATICS}

Hypsidracon MEYRICK, 1934

Hypsidracon MEYRICK, 1934, Exotic Microlepid., 4: 256. Type-species: Hypsidracon saurodoxa MEYRICK, 1934; Uganda. BROWN (2005): 391.

\section{Diagnosis}

Hypsidracon shows some similarity to Rhodotoxotis DiAKONOFF, 1992: both have a rigid, bifurcate uncus. Although the latter was included originally in Eucosmini, a similar signa occurs occasionally in Eudemis HÜBNER, [1825] and Phaecasiophora GROTE, 1873 (both Olethreutini). In the latter the distal part of the tegumen has two hairy processes which usually are interpreted as socii. However, Hypsidracon has typical Tortricidae socii in addition to the terminal processes; hence, those structures are referred to as processes of the uncus.

\section{Distribution}

Afrotropical region: Kenya and Uganda. Two species known.

\section{Comments}

H. saurodoxa MEYRICK, 1934 and its synonym Olethreutes orestera BRADLEY, 1965 are from Ruwenzori, Uganda (synonymized by RAzOwSKI et al. 2010). BRADLEY (1965) illustrated the female which has only one signum (compared to Gnathodracon gen. n., which has two). 
The systematic position requires additional study. BRADLEY (1965) placed his species in Olethreutini, BROwN (2005) in Archipini, and I include the genus in Olethreutinae without tribal assignment.

\section{Hypsidracon kururana sp. $\mathrm{n}$.}

(Figs 1, 10)

\section{Diagnosis}

H. kururana is similar to H. saurodoxa MEYRICK, 1934, but $H$. kururana has more slender valva and a produced, spiny ventrocaudal edge of the cucullus.

\section{Description}

Wing span $19 \mathrm{~mm}$. Head greyish, thorax grey with base of tegula darker. Forewing slender, indistinctly tapering terminally; costa weakly convex; termen oblique, straight. Ground colour whitish, densely suffused and sprinkled with grey-brown; costal strigulae indistinct. Marking grey-brown represented by costal half of median fascia followed by a shadow towards wing apex. Cilia brownish grey, whiter at tornus. Hindwing whitish, slightly mixed brownish on peripheries; cilia whitish.

Variation. Wing span 17-19 mm; ground colour of forewing more or less grey, in a few specimens strongly suffused brownish grey; markings dark, in a few examples edged whitish, forming a more or less distinct triangle; additional concolorous spot subapically and dark suffusion of wing base.

Male genitalia (Fig. 1). Uncus arms slender, pointed terminally; socius sparsely hairy, tapering apicad; valva rather slender with small neck and short, shallow ventral incision; cucullus elongate with weak ventral lobe and distinct marginal spines; aedeagus moderate, simple.

Female unknown.

\section{Biology}

Moths collected in February and April at altitudes of 2910-2980 m.

\section{Etymology}

The specific name refers to the collecting locality of the Kururu Falls.

\section{Material examined}

Holotype male: "Coll. Museum Tervuren. Kenya: Aberdares Nat. P.[ark], Karuru Falls alt. 2980 m, 00.22S 36.54E (N6), 12/04/2000, Ugo Dall'Asta"; GS 00655. Paratypes: 9 males from the same locality 23 and 24.II (two specimens) and 12.IV; one collected at Fishing Lodge Pond, 2910 m, 10.IV all in 2000.

\section{Gnathodracon gen. n.}

Type species: Gnathodracon orbiculina sp. n. 


\section{Diagnosis}

On the basis of the structure of the uncus (similar to Hypsidracon) and the presence of large scent organs (brushes and bunches) of the male hind leg, this genus is included in Olethreutini. The signa are funnel-shaped, similar to those in many Eucosmini, but are also similar to those of the Eudemina-group of olethreutine genera. The sterigma is simplified, resembling that in Eucosmini. DIAKONOFF (1992) described Rhodotoxotis, a similar genus in Eucosmini, based on the venation of the hindwing, but the uncus of Rhodotoxotis is a simple bifurcate process.

\section{Description}

Labial palpus 1.5, curved upwards. No costal fold. Male hindwing of G. lukimayumbe with well-developed anal lobe (not extending in remaining species). Venation: In forewing radial arm bent at R1; R5 to termen beneath apex; base of CuA2 opposite 2/3 distance R1R2; chorda strong, originating near base of R2; M-stem well developed. In hindwing RsM1 parallel in basal fourth; M2 separate from M3; M3-CuA1 connate. Hindlegs with distinct groups of scent scales (Fig. 14).

Male genitalia. Uncus broad basally with two terminal, sharp, folded lobes, hairy ventrolaterally; socius absent; gnathos fully developed, arms broad basally; valva broad basally, more or less tapering terminad without neck and ventral incision; cucullus weakly differentiated; sacculus angulate, setose; series of long, sparse setae along ventral edge of sacculus and cucullus; basal cavity broad, short or elongate; basal process ill-defined; aedeagus short; cornuti in cluster.

Female genitalia (known in one species only). Ovipositor and apophyses short; sterigma weakly sclerotized except for vicinity of ostium bursae; sclerite of antrum present; cingulum absent; signa two horns with ill-defined basal plate.

Biology

Moths collected in the forests at altitudes of 50-320 m.

\section{Distribution}

Congo and Kenya. Six species known.

Etymology

The generic name refers to the name of Hypsidracon MEYRICK, 1934 and Latin: gnathos - a part of male genitalia.

\section{Gnathodracon orbiculina sp. $\mathbf{n}$.}

(Figs 2, 11)

\section{Diagnosis}

The male genitalia of G. orbiculina are similar to those of G. arabuko, but those of the former have a broad, angulate sacculus. The female genitalia resemble those of Rhodocosmaria plutostola DIAKONOFF, 1992 from Madagascar, but the signa of the latter are unequal, and the sclerite distad of the ostium bursae is strongly convex. 


\section{Description}

Wing span $19.5 \mathrm{~mm}$. Head and thorax pale cream brown; frons, median part of vertex, and proximal and distal parts of thorax dark brown; dorsum of median joint of labial palpus brownish. Forewing broad, not expanding terminally; costa convex; termen straight to middle, not oblique. Ground colour cream, slightly tinged brownish; suffusions and strigulation browner; costal strigulae fine, cream; divisions dark brown. Markings dark brown, basal blotch and median fascia more or less convex posteriorly, rounded blotch subterminally, also weakly edged proximally. Cilia brown, more cream at tornus. Hindwing brown; cilia brownish cream.

Variation. Wing span of one female $16 \mathrm{~mm}$, colouration with greater contrast than in holotype.

Male genitalia (Fig. 2). As described for the genus, with broad base of uncus, broad, angulate sacculus and slender postmedian part of valva; spinulation of sacculus dense; aedeagus short; cornuti short.

Female genitalia unknown.

\section{Etymology}

The name is based on the forewing subterminal blotch; Latin: orbiculus - a target, -ina: a suffix indicating diminution.

\section{Material examined}

Holotype male: "Congo, Dem. Rep.; Bas-Congo 320 m, N.R. Luki-Mayumbe 05.27'S 13.05'E, 22.III.2006, leg. J. \& W. De Prins"; GS 00402. Paratypes: 3 identically labelled males.

\section{Gnathodracon arabuko sp. n.}

(Figs 3, 12)

\section{Diagnosis}

G. arabuko is very closely related and similar to G. orbiculina, but in G. arabuko the forewing fringe is mostly rust-coloured and the sacculus is convexly rounded.

\section{Description}

Wing span $17 \mathrm{~mm}$ (15-19 $\mathrm{mm}$ in paratypes). Head dark rust brown, labial palpus paler, brown; thorax cream brown, tegula and collar dark brown; two dark rust brown spots in anterior part of thorax, crest concolorous. Forewing as in G. orbiculina. Ground colour cream with brown admixture; suffusions and strigulation more or less dark, brown; costal strigulae cream; divisions and apex dark brown. Markings: basal blotch rudimentary in form of strigulate suffusion; median fascia dark brown, broad in costal third; subterminal rounded blotch concolorous. Cilia rust to beyond M3, then cream. Hindwing brownish grey; cilia cream grey.

Male genitalia (Fig. 3). Processes of uncus rather slender; gnathos arms delicate; valva 
broad basally, moderately slender posteriorly; sacculus convex with small postbasal group of short setae and large angular group of longer spines connected with vestiture of cucullus; aedeagus short, cornuti numerous.

Female unknown.

\section{Biology}

The moths were collected in forests at altitudes between 50 and $253 \mathrm{~m}$.

\section{Etymology}

The name refers to the type locality.

\section{Material examined}

Holotype male: "Kenya, Arabuko Sokoke Forest, $6 \mathrm{~km} \mathrm{~W}$ Gede, $70 \mathrm{~m}, 03.17 \mathrm{~S}$ 039.59'E, 27.III.2004, leg. J. \& W. De Prins", not dissected. Paratypes: 7 males similarly labelled as above but $15 \mathrm{~km} \mathrm{~W}$ Gede, $50 \mathrm{~m}, 01 . I V .2004 ; 18 . I I I .2004,18 \mathrm{~km} \mathrm{~W}$ Gede, $50 \mathrm{~m}$, GS 00382; 20.III.2004, $10.5 \mathrm{~km} \mathrm{~W} \mathrm{Gede,} 50 \mathrm{~m}$. Two specimens from Arabuko Sokoke, 23.VIII.1999, Q5 Branchy, stegia woodland, U. Dall'Asta, Hg+Hal. and 17.III.1999 (Q4 Branch), and one from same locality, mixed forest, $253 \mathrm{~m}$, 1.XII.2000, same collector.

\section{Gnathodracon yuhana sp. $\mathbf{n}$.}

(Figs 4, 13)

\section{Diagnosis}

In facies, G. yuhana is similar to G. orbiculina. The male genitalia are similar to those of G. arabuko, but G. yuhana has a slenderer valva than the latter, tapering terminad, with fused ventral groups of setae.

\section{Description}

Wing span $21 \mathrm{~mm}$. Head and thorax worn, probably brownish cream. Forewing not expanding terminally; costa and termen somewhat convex. Ground colour (rubbed) brownish cream, suffused and sprinkled brown. Markings brown typical of the genus. Cilia absent. Hindwing brownish; cilia more cream posteriorly.

Male genitalia (Fig. 4). Processes of uncus long; basal halves of arm of gnathos broad, terminal plate rounded; basal third of valva broad, tapering, terminal part slender, pointed; sacculus gradually convex with basal, median and angular groups of setae, the latter separate from the median, connected with cucullar group; aedeagus small.

Female unknown.

\section{Biology}

The moth was collected in primary lowland rain forest.

\section{Material examined}

Holotype male: "Korup Nat. Park: Mt Yuhan, No grid ref. 08/03/89, nigh[!] 22.00-01.00 $600 \mathrm{~m}$, Appr. $3 \mathrm{k}$, NW of Nikondo-Kondo, trap o[n] forested ridge out look on down slope through trees, Prim.[ary] lowland rain forest"; GS 00382. 

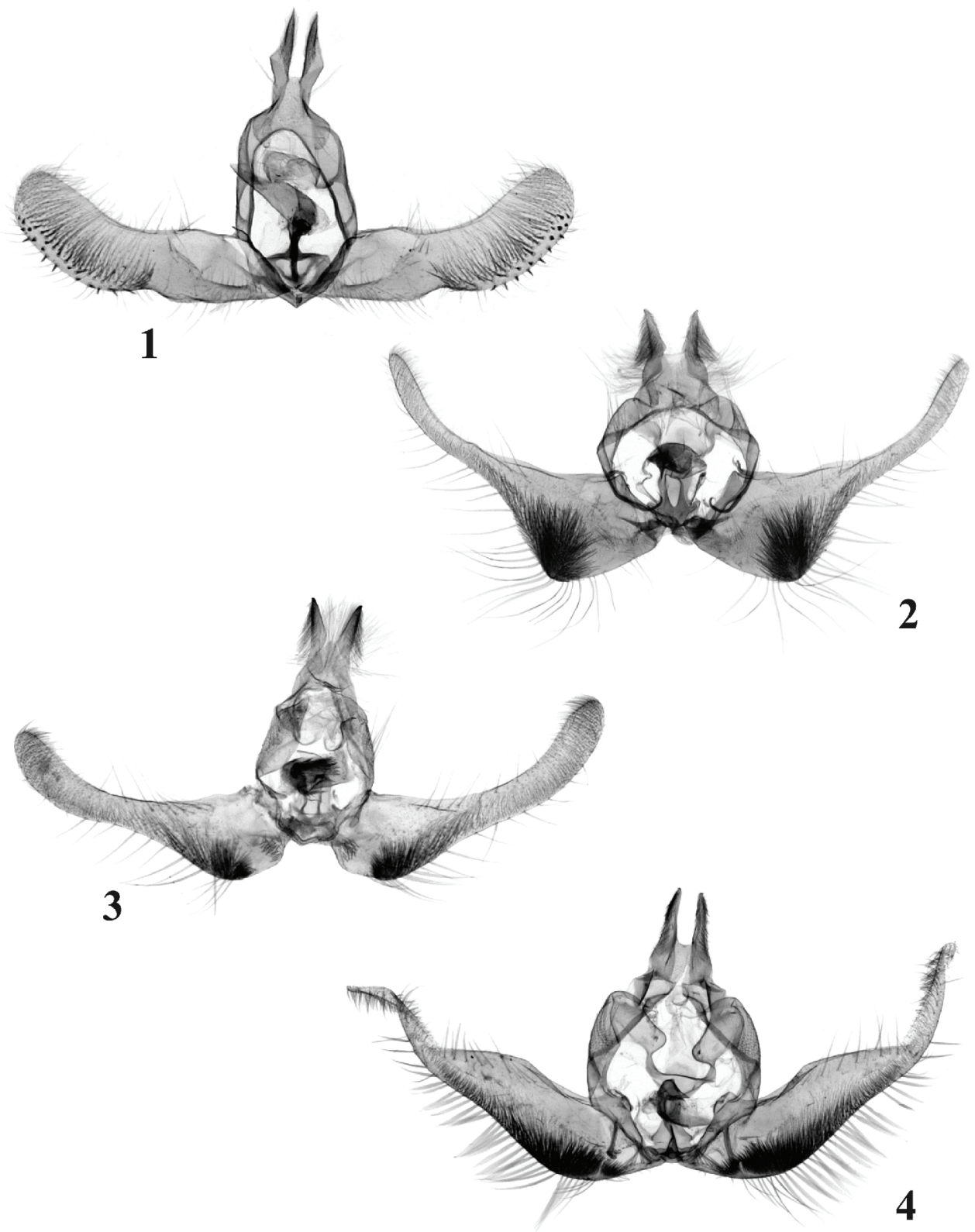

Figs 1-4. Male genitalia: 1 - Hypsidracon kururana sp. n., holotype, 2 - Gnathodracon orbiculina sp. n., holotype, 3 - Gnathodracon arabuko sp. n., holotype, 4 - Gnathodracon yuhana sp. n., holotype. 

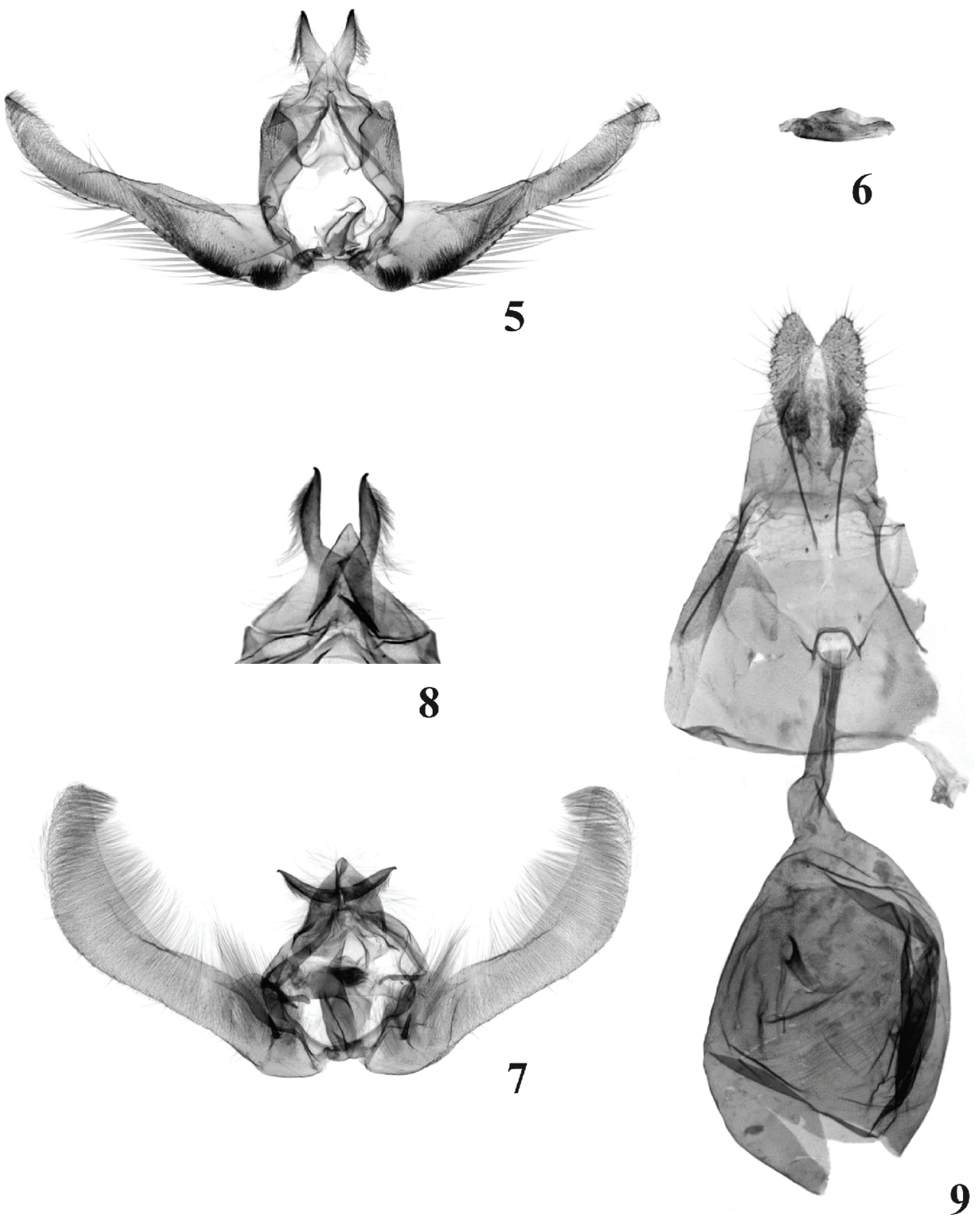

Figs 5-9. Male and female genitalia: 5 - Gnathodracon lukimayumbe sp. n., holotype, 6 Gnathodracon lukimayumbe sp. n., holotype, aedeagus, 7 - Gnathodracon monospina sp. n. holotype, 8 - Gnathodracon monospina sp. n., paratype, GS 00627, tegumen, 9 - Gnathodracon lukimayumbe sp. n., paratype, GS 00401. 

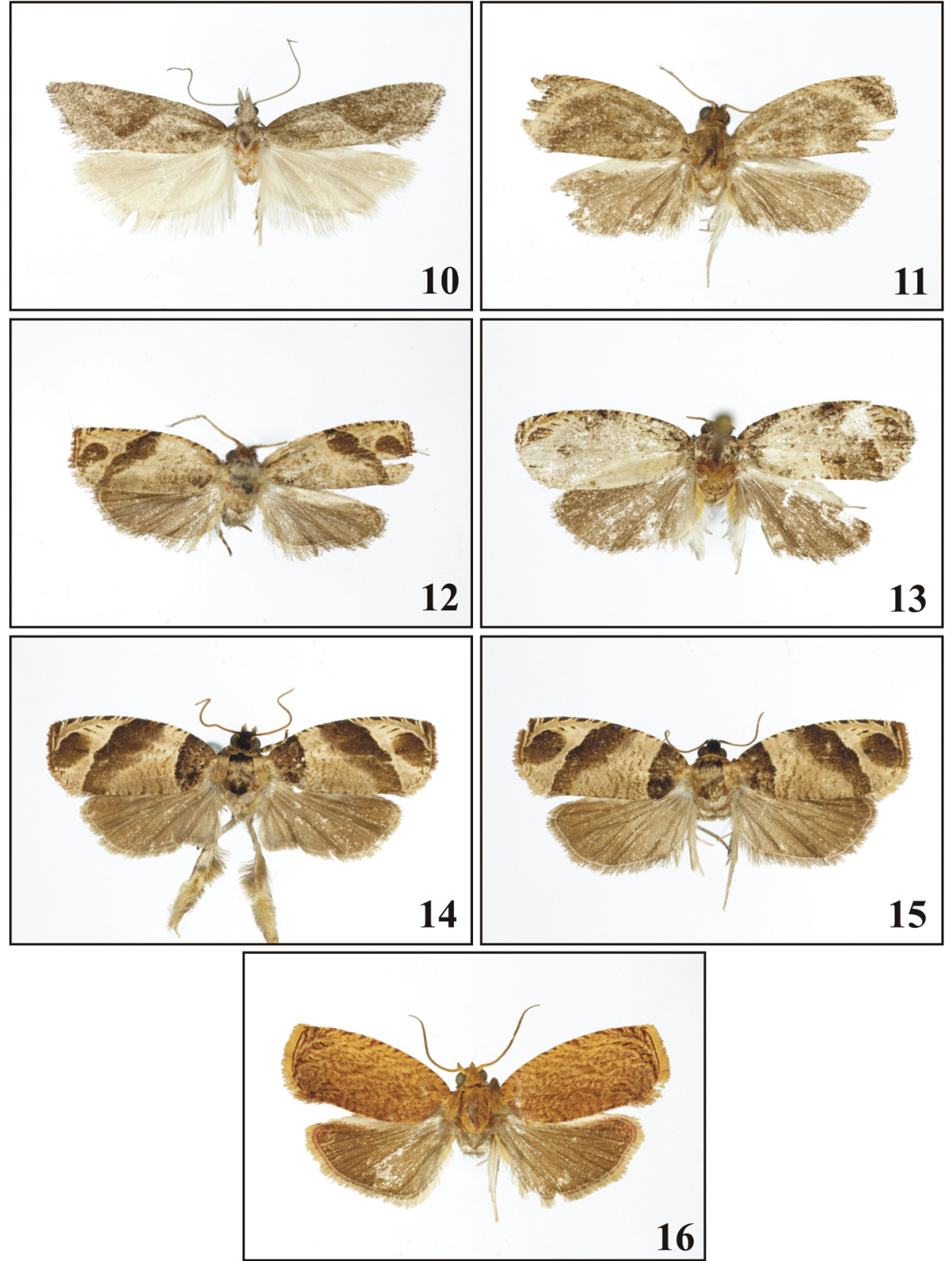

Figs 10-16. Adults: 10 - Hypsidracon kururana sp. n., holotype, 11 - Gnathodracon orbiculina sp. n., holotype, 12 - Gnathodracon arabuko sp. n., holotype, 13 - Gnathodracon yuhana sp. n., holotype, 14 - Gnathodracon lukimayumbe sp. n., holotype, 15 - Gnathodracon lukimayumbe sp. n., paratype, GS 00401, 16 - Gnathodracon monospina sp. n., holotype. 


\section{Gnathodracon lukimayumbe sp. $\mathbf{n}$.}

(Figs 5, 6, 9, 14, 15)

\section{Diagnosis}

This species is closely related to G. yuhana, but G. lukimayumbe has shorter processes of the uncus, a shorter and broader valva, and separate groups of saccular setae.

\section{Description}

Wing span $18 \mathrm{~mm}$. Head brownish; thorax cream brown, scaled brownish. Forewing as in G. yuhana. Ground colour (wing rubbed) cream, densely sprinkled and suffused brownish; costal strigulae fine, cream; divisions small, brownish. Markings brown diffuse: basal blotch connected medially with median fascia; subterminal fascia broad, not forming subterminal blotch. Cilia damaged. Hindwing brownish; cilia creamer.

Male genitalia (Figs 5, 6). Processes of uncus moderately long, broadest medially; gnathos arm broad proximally; valva slender; sacculus convex; median group of setae separated from angular group; aedeagus small, extending ventro-posteriorly.

Female genitalia (Fig. 9). As described for the genus.

\section{Biology}

The moth was collected at an altitude of $320 \mathrm{~m}$.

\section{Material examined}

Holotype male: "Congo, Dem. Rep.; Bas-Congo 320 m, N.R. Luki-Mayumbe 05.27'S 13.05'E, 29.III.2006, leg. J. \& W. De Prins"; GS 00399.

\section{Gnathodracon monospina sp. n.}

(Figs 7, 8, 16)

\section{Diagnosis}

G. monospina is most similar to G. strigulana (KARISCH, 2009), comb. n. from Tsinguidi, Democratic Republic of Congo, but the forewing of the latter is oval, broadest near middle, and the apex atrophied; the markings consist of five long, oblique, slender fasciae; and the termen is brown. The valva of G. monospina is broader than that of G. strigulana, the sacculus lacks the distinct setae present in all other species, but has a strong postbasal spine, and the terminal part of the aedeagus is short.

\section{Description}

Wing span $17 \mathrm{~mm}$. Head and thorax yellowish ferruginous, labial palpus browner dorsally. Forewing shape as in all other congeners. Ground colour cream ferruginous; strigulae and dots brownish ferruginous, suffusions darker. Costal strigulae concolorous with ground colour, division with maculation. Markings ill-defined, concolorous with some browner marks; subterminal fascia slender with some brownish dashes; termen marked by 
brown line. Cilia cream orange. Hindwing brownish, darker terminally, tinged rust at apex; cilia cream, mixed with orange in apical third.

Male genitalia (Figs 7, 8). Processes of uncus slender; valva moderately broad; sacculus somewhat convex with strong spine near base dorsally; cucullus indistinct; saccular spines absent; aedeagus extending ventro-posteriorly; cornuti short.

Female unknown.

\section{Biology}

The moths were collected in submontane forest with scrubby low vegetation at altitudes of 320 and $1150 \mathrm{~m}$.

\section{Material examined}

Holotype male: "Congo, Dem. Rep.; Bas-Congo 320 m, Nat. Res. Luki-Mayumbe 05.37'S 13.05'E, 16.V.2007, leg. J. \& W. De Prins"; GS 00430. Paratypes: 2 males identically labelled as above and one male from Mount Cameroon, Mapanja 98.4'E 45.4', $1150 \mathrm{~m}, 3.5 \mathrm{~km}$ NW of Mapanja, SE side Mt. Cameroon. Trap on bottom of valley, submontane forest scrubby low vegetation; GS 00629 .

\section{Comments}

The specimens examined are very similar to those of G. strigulana described from the Democratic Republic of Congo. KARISCH (2009) writes that the cilia of the forewing of G. strigulana are brown whilst in the examined specimen they are entirely cream orange; for other differences, see the diagnosis above.

\section{REFERENCES}

AARVIK L. 2004. Revision of the subtribe Neopotamiae (Lepidoptera: Tortricidae) in Africa. Norwegian Journal of Entomology 51: 71-155.

AARVIK L., KARISCH T. 2009. Revision of Multiquestia KARISCH (Lepidoptera: Tortricidae: Grapholitini). Zootaxa 2026: 18-32.

BRADLEY J.D. 1965. Microlepidoptera. [In:] Ruwenzori Expedition 2(12). British Museum (NH): 81-148.

BRown J.W. 2005. Tortricidae (Lepidoptera). [In:] World Catalogue of Insects, Apollo Books, Stenstrup 5: 1-741.

DiAKonofF A. 1992. Tortricidae from Madagascar. Part 2. Olethreutinae, 7. Annales de la Société Entomologique de France (Nouvelle série) 28: 37-71.

KARISCH T. 2008. Zur Kenntnis der Wickler von Bioco (Lepidoptera, Tortricidae). Lambillionea 108: 83-94.

KARISCH T. 2009. Ein neuer Wickler aus dem Kongo (Lepidoptera, Tortricidae). Carolinea 67: 157-158.

RAZOWSKI J., KRÜGER M. 2007. An illustrated catalogue of the type specimens of Tortricidae in the Transvaal Museum, Pretoria (Lepidoptera: Tortricidae). SHILAP Revista de Lepidopterologia 35: 103-179.

Razowski J., Trematerra P. 2008. On some Tortricidae (Lepidoptera) from Mozambique. Redia 91: $33-40$. 
Razowski J. Aarvik L., De Prins J. 2010. An annotated catalogue of the types of Tortricidae (Lepidoptera) in the collection of the Royal Museum for Central Africa (Tervuren, Belgium) with descriptions of new genera and new species. Zootaxa 2469: 1-77.

Received: July 25, 2012

Accepted: September 5, 2012 